\title{
EFFECT OF AN AMINO ACID IMBALANCE ON INTESTINAL SUCRASE AND LEUCINE AMINO- PEPTIDASE ACTIVITIES IN RATS
}

\author{
Toshizo Kimura, Fumihiko Horio, and Akira Yoshida ${ }^{1}$ \\ Laboratory of Nutritional Biochemistry, Department of Agricultural Chemistry, \\ Nagoya University, Nagoya 464, Japan
}

(Received July 2, 1979)

\begin{abstract}
Summary In order to investigate the relationship between dietary amino acids and protein, as well as the activities of intestinal sucrase and leucine aminopeptidase in rats, the effects of an amino acid imbalance on these enzyme activities were studied. The amino acid imbalance was created by adding $8 \%$ of an indispensable amino acid mixture lacking threonine to a $6 \%$ casein diet supplemented with $0.3 \%$ methionine. The food intake and growth of rats fed the imbalanced diet ad libitum were depressed, and the segmental weights of the small intestine and its sucrase activity were clearly lower than those of rats fed the basal diet. The effect of the imbalanced diet under pair-feeding condition on the sucrase activity was similar to that under an ad libitum feeding condition. The food intake and segmental sucrase activity, that is, sucrase activity per length of the small intestine, of rats injected with cortisol $(1 \mathrm{mg} /$ day $)$ and fed the imbalanced diet were not depressed, although administration of insulin (1.5 U/day) had no effect on the food intake or segmental sucrase activity. Force-feeding stimulated growth of rats receiving the imbalanced diet, as well as increasing their segmental sucrase activities. The effects of these different conditions on the leucine aminopeptidase activity of rats receiving the imbalanced diet were obscure. These results suggest that changes in segmental sucrase activity might be mediated by stimulating factors in food intake affected by the composition of ingested amino acids and protein together with sucrose in the gastrointestinal lumen.

Keywords threonine, amino acid imbalance, cortisol, small intestine, sucrase, leucine aminopeptidase
\end{abstract}

In previous studies (1-5) we reported that the segmental activities, that is, activities per length of the small intestine, of intestinal sucrase [EC 3.2.1.26] and leucine aminopeptidase [EC 3.4.11.1, LAPase] of rats fed a high sucrose diet were

1 木村利三, 堀尾交彦, 吉田 昭 
affected by the composition and content of amino acids and protein in the diet. However, there was no difference in the segmental activities of these enzymes between rats fed a protein-free diet and a diet supplemented with L-methionine and L-threonine, although the segmental weights of the small intestine and its mucosa in rats fed the latter were significantly higher than those of rats fed the former (5). Furthermore, it was observed that regardless of the amount of food consumed the segmental sucrase activity in rats fed the same diet remained at a constant level $(2,6)$. These findings suggested that the effects of dietary components on the segmental sucrase activity might be mediated by unknown factors affected by the composition and content of ingested amino acids and protein together with dietary sucrose in the gastrointestinal lumen (5). On the other hand, depressions in food intake and growth are characteristic signs in amino acid imbalances created by an addition of a large amount of a mixture of indispensable amino acids to a low protein diet devoid of growth-limiting amino acids (7-9). Several studies, however, have demonstrated that if food intake can be maintained by insulin (10) or cortisol $(8)$ injection, or by force-feeding $(7,9)$ rats fed an amino acid-imbalanced diet grow well and appear to be as healthy as control rats fed a basal diet.

The present study was undertaken to observe the effect, under different conditions, of a threonine-imbalanced diet on the segmental weights of the small intestine and its mucosa, and the activities of intestinal sucrase and LAPase. The relationships between dietary amino acids and protein, and these enzyme activities were investigated.

\section{EXPERIMENTAL}

Animals and diets. Male rats of the Wistar strain ${ }^{2}$ weighing 70 to $90 \mathrm{~g}$ were used and were individually housed in suspended wire-bottom cages in a room lit from 8:00 AM to 8:00 PM and maintained at 23 to $25^{\circ} \mathrm{C}$. All rats were fed the basal diet as described below for at least 3 days to allow them to adjust to the environment before each experiment was begun. The basal diet contained $6 \%$ of casein supplemented with $0.3 \%$ L-methionine plus the following: (in percent) salt mixture (11), 4; corn oil, 5; vitamin mixture (12), 1; choline chloride, 0.2 and a starch-sucrose mixture $(1: 1)$ as carbohydrate to make up to $100 \%$. Retinylpalmitate, 2,500 IU; ergocalciferol, $250 \mathrm{IU}$ and all-rac- $\alpha$-tocopherol, $5 \mathrm{mg}$ were added to $100 \mathrm{~g}$ of the diet. An amino acid imbalance was created by adding to the basal diet a mixture of amino acids ${ }^{3}$ devoid of threonine (7) (Table 1).

Experiment 1. The effects of the threonine-imbalanced diet on changes in body weight, food intake, segmental weights of the small intestine and its mucosa, and intestinal enzyme activities were studied. Rats were fed ad libitum either the basal diet or the threonine-imbalanced diet for 5 days, and then were killed. The

\footnotetext{
${ }^{2}$ Shizudokyo, Hamamatsu, Shizuoka, Japan.

${ }^{3}$ Ajinomoto Co., Inc. Tokyo.
} 
Table 1. Composition of basal and threonine-imbalanced diets.

\begin{tabular}{lcc}
\hline & $\begin{array}{c}\text { Basal diet } \\
(\%)\end{array}$ & $\begin{array}{c}\text { Threonine-imbalanced } \\
\text { diet } \\
(\%)\end{array}$ \\
\hline Casein & 6 & 6 \\
Corn oil & 5 & 5 \\
Salt mixture & 4 & 4 \\
Vitamin mixture $^{1}$ & 1 & 1 \\
Choline chloride $^{\text {L-Methionine }}$ & 0.2 & 0.2 \\
L-Tryptophan & 0.3 & 0.3 \\
L-Leucine & - & 0.36 \\
L-Isoleucine & - & 1.25 \\
L-Valine & - & 1.78 \\
L-Histidine HCl & - & 1.94 \\
L-Phenylalanine & - & 0.54 \\
L-Lysine $\mathrm{HCl}$ & - & 0.80 \\
Sucrose: starch $(1: 1)$ & 83.5 & 1.33 \\
\hline
\end{tabular}

1 See EXPERIMENTAL section for composition.

small intestine was removed and slit longitudinally after rinsing with cold saline. A jejunal segment representing the second $15-\mathrm{cm}$ segment distal to the pylorus was cut. The mucosa was scraped with a piece of glass, homogenized with cold distilled water and used for determinations of protein and enzyme activities.

Experiment 2. There was a significant difference in the amount of food consumed between rats fed ad libitum the basal diet and the threonine-imbalanced diet. This experiment was carried out to observe the effects of the threonine imbalance under a pair-feeding condition on the activities of intestinal enzymes. Animals were separated into two groups; the basal group and the threonineimbalance group. Rats in the latter group were fed ad libitum the threonineimbalanced diet for 2 days. Rats in the former group were pair-fed the basal diet against the threonine-imbalance group, but were allowed access to the basal diet daily at 6:00 PM to synchronize the food intake pattern with that of the threonineimbalance group. After 2 days of the experimental feeding rats were treated as in experiment 1 .

Experiments 3 and 4 . These experiments were undertaken to examine the effect of hormones, insulin and cortisol, on food intake, growth, segmental weights of the small intestine and its mucosa, and intestinal enzyme activities in rats fed the threonine-imbalanced diet. In experiment 3, rats were divided into 4 groups, which were respectively fed ad libitum either the basal diet or the threonine-imbalanced diet and were subcutaneously injected with either saline or insulin, $1.5 \mathrm{U} / \mathrm{rat} / \mathrm{day}$, at 3 to 4 PM daily. After 4 days of the experimental feeding, all rats were treated as in experiment 1 . In experiment 4 , the experimental procedure was carried out basically as in experiment 3 , except rats were intraperitoneally injected with either 
saline or cortisol (hydrocortisone acetate), $1 \mathrm{mg} / \mathrm{rat} / \mathrm{day}$, at 3 to $4 \mathrm{PM}$ daily, and were fed ad libitum the experimental diets for 3 days.

Experiment 5. The purpose of this experiment was to observed the effects of force-feeding of the threonine-imbalanced diet on growth, segmental weights of the small intestine and its mucosa, and intestinal enzyme activities. The diets used in this experiment were essentially the same as those used in the previous experiments except for two changes: (a) micropulverized casein was used instead of the regular casein; (b) sucrose was used as the sole source of carbohydrate. Rats were divided into two groups, rats in one group were fed ad libitum either the basal diet or the threonine-imbalanced diet for 8 days. Rats in the other group were force-fed the basal diet in increasing quantities each day for 7 days to allow them to adapt to the tube-feeding regimen. At the end of the adaptation period, animals were divided into two groups, which were force-fed either the basal diet or the threonineimbalanced diet, respectively, in an amount approximately equal to that consumed when on the basal diet voluntarily for 8 days. The diets were blended with deionized water so that each milliliter of diet mixture contained $0.7 \mathrm{~g}$ of dry diet, and this was given three times daily: at 9 AM, 3 PM and 10 PM. Rats force-fed were weighed daily before the morning feed. After the experimental feeding period, they were treated by the experimental procedure similar to that in the previous experiments.

Analytical procedure. Sucrase activity was determined by the method of DAHLQVIST (13), and LAPase activity was measured by the method of GolDBERG and Rutenburg (14). The protein content in the intestinal mucosa was determined by the method of LowRY et al.(15) using bovine serum albumin as a standard.

Statistical analysis. Student's " $t$ " test was used to determine significant differences between treatment means(16).

\section{RESULTS}

The results of experiment 1 are shown in Table 2. The food intake, gain in body weight, liver weight and the segmental weights of the small intestine and its mucosa of rats fed ad libitum the threonine-imbalanced diet were clearly lower than those of rats fed the basal diet. Intestinal sucrase activity per mg of protein in the threonine-imbalance group was relatively low compared to that of the basal group, although there was no statistical difference. However, sucrase activity per segment, that is, segmental sucrase activity, of the latter was significantly higher than that of the former. On the other hand, there were no differences in LAPase activity per mg protein or per segment between the groups. Table 3 shows the results of experiment 2. There were no differences in changes in body weight or in liver weight between the groups. The segmental weights of the small intestine and its mucosa and intestinal sucrase activity of the threonine-imbalance group were low compared with those of the basal group, but except for differences in sucrase activities these differences were not statistically significant. The results of experiment 3 are shown 
Table 2. Effect of a threonine-imbalanced diet on intestinal sucrase and leucine aminopeptidase (LAPase) activities (Experiment 1).

\begin{tabular}{|c|c|c|c|}
\hline Diet & & Basal & $\begin{array}{l}\text { Threonine- } \\
\text { imbalanced }\end{array}$ \\
\hline No. of rats & & 4 & 5 \\
\hline Initial body wt. & $\mathrm{g}$ & $72.3 \pm 2.1^{1, \mathrm{a}}$ & $70.8 \pm 1.7^{\mathrm{a}}$ \\
\hline Body wt. gain & $\mathrm{g} / 5$ days & $11.0 \pm 4.4^{\mathrm{a}}$ & $-4.2 \pm 1.7^{b}$ \\
\hline Food intake & g/day & $9.8 \pm 1.1^{\mathrm{a}}$ & $5.8 \pm 0.2^{\mathrm{b}}$ \\
\hline Liver wt. & $\mathrm{g}$ & $4.68 \pm 0.21^{\mathrm{a}}$ & $3.33 \pm 0.15^{\mathrm{b}}$ \\
\hline Small intestine & $\mathrm{mg} /$ segment $^{2}$ & $618 \pm 26^{\mathrm{a}}$ & $514 \pm 15^{b}$ \\
\hline Mucosa & $\mathrm{mg} /$ segment & $446 \pm 14^{a}$ & $357 \pm 12^{\mathrm{b}}$ \\
\hline \multirow[t]{2}{*}{ Mucosal protein } & $\mathrm{mg} / \mathrm{g}$ mucosa & $144 \pm 9^{a}$ & $138 \pm 5^{\mathrm{a}}$ \\
\hline & $\mathrm{mg} /$ segment & $64.4 \pm 5.6^{\mathrm{a}}$ & $48.4 \pm 2.3^{b}$ \\
\hline \multicolumn{4}{|l|}{ Sucrase activity } \\
\hline & $\mathrm{U}^{3} / \mathrm{mg}$ protein & $5.16 \pm 0.75^{\mathrm{a}}$ & $4.69 \pm 0.41^{\mathrm{a}}$ \\
\hline & U/segment & $320 \pm 15^{a}$ & $232 \pm 25^{b}$ \\
\hline \multicolumn{4}{|l|}{ LAPase activity } \\
\hline & $\mathrm{U} / \mathrm{mg}$ protein & $3.18 \pm 0.37^{\mathrm{a}}$ & $3.61 \pm 0.21^{\mathrm{a}}$ \\
\hline & $\mathrm{U} /$ segment & $201 \pm 19^{a}$ & $178 \pm 14^{\mathrm{a}}$ \\
\hline
\end{tabular}

1 Mean \pm SE; means within line not sharing a common superscript letter differ significantly $(p<0.05)$.

2 Second $15-\mathrm{cm}$ segment from the pylorus.

3 Micromoles of substrate split per hour.

Table 3. Effect of a threonine-imbalanced diet on intestinal sucrase and leucine aminopeptidase (LAPase) activities (Experiment 2).

\begin{tabular}{lrcc}
\multicolumn{1}{c}{ Diet } & & Basal & $\begin{array}{c}\text { Threonine- } \\
\text { imbalanced }\end{array}$ \\
\hline Initial body wt. & $\mathrm{g}$ & $83.8 \pm 2.6^{1 . \mathrm{a}}$ & $81.8 \pm 1.9^{\mathrm{a}}$ \\
Body wt. gain & $\mathrm{g} / 2$ days & $-1.5 \pm 1.2^{\mathrm{a}}$ & $-2.5 \pm 0.6^{\mathrm{a}}$ \\
Food intake & $\mathrm{g} /$ day & 5.3 & 5.8 \\
Liver wt. & $\mathrm{g}$ & $4.12 \pm 0.14^{\mathrm{a}}$ & $4.03 \pm 0.11^{\mathrm{a}}$ \\
Small intestine & $\mathrm{mg} /$ segment ${ }^{2}$ & $600 \pm 29^{\mathrm{a}}$ & $543 \pm 21^{\mathrm{a}}$ \\
Mucosa & $\mathrm{mg} /$ segment & $416 \pm 18^{\mathrm{a}}$ & $365 \pm 15^{\mathrm{a}}$ \\
Mucosal protein & $\mathrm{mg} / \mathrm{g}$ mucosa & $135 \pm 4.5^{\mathrm{a}}$ & $126 \pm 3.3^{\mathrm{a}}$ \\
& $\mathrm{mg} /$ segment & $56.1 \pm 2.2^{\mathrm{a}}$ & $45.9 \pm 2.0^{\mathrm{b}}$ \\
Sucrase activity & $\mathrm{U}$ & $6.33 \pm 0.38^{\mathrm{a}}$ & $4.57 \pm 0.20^{\mathrm{b}}$ \\
& $\mathrm{U} / \mathrm{mg}$ protein & $355 \pm 7^{\mathrm{a}}$ & $210 \pm 11^{\mathrm{b}}$ \\
& $\mathrm{U} /$ segment & $3.95 \pm 0.18^{\mathrm{a}}$ & $4.76 \pm 0.22^{\mathrm{b}}$ \\
LAPase activity & $\mathrm{U} / \mathrm{mg}$ protein & $222 \pm 11^{\mathrm{a}}$ & $219 \pm 12^{\mathrm{a}}$ \\
& & &
\end{tabular}

1 Mean \pm SE $(n=4)$; means within line not sharing a common superscript letter differ significantly $(p<0.05)$.

2 Second $15-\mathrm{cm}$ segment from the pylorus.

${ }^{3}$ Micromoles of substrate split per hour. 
Table 4. Effect of insulin on growth, food intake and intestinal sucrase and leucine aminopeptidase (LAPase) activities in rats fed a threonine-imbalanced diet (Experiment 3).

\begin{tabular}{|c|c|c|c|c|c|}
\hline Diet & & Basal & Basal & $\begin{array}{l}\text { Threonine- } \\
\text { imbalanced }\end{array}$ & $\begin{array}{l}\text { Threonine- } \\
\text { imbalanced }\end{array}$ \\
\hline Injection & & Saline & Insulin ${ }^{1}$ & Saline & Insulin ${ }^{1}$ \\
\hline Initial body wt. & g & $94.4 \pm 1.7^{2, \mathrm{a}}$ & $94.4 \pm 3.0^{\mathrm{a}}$ & $94.2 \pm 1.7^{\mathrm{a}}$ & $94.2 \pm 2.0^{\mathrm{a}}$ \\
\hline Body wt. gain & $\mathrm{g} / 4$ days & $10.0 \pm 2.1^{\mathrm{a}}$ & $11.4 \pm 0.7^{\mathrm{a}}$ & $0.6 \pm 2.0^{\mathrm{b}}$ & $0.4 \pm 1.4^{b}$ \\
\hline Food intake & g/day & $12.4 \pm 0.9^{\mathrm{a}}$ & $13.2 \pm 0.8^{\mathrm{a}}$ & $8.6 \pm 0.7^{b}$ & $9.1 \pm 0.7^{b}$ \\
\hline Liver wt. & $\mathrm{g}$ & $5.82 \pm 0.21^{\mathrm{a}}$ & $5.98 \pm 0.17^{\mathrm{a}}$ & $5.08 \pm 0.27^{\mathrm{a}, \mathrm{b}}$ & $5.10 \pm 0.17^{\mathrm{b}}$ \\
\hline Small intestine & $\mathrm{mg} /$ segment $^{3}$ & $604 \pm 35^{\mathrm{a}}$ & $621 \pm 28^{\mathrm{a}}$ & $518 \pm 22^{b}$ & $500 \pm 25^{b}$ \\
\hline Mucosa & $\mathrm{mg} /$ segment & $436 \pm 23^{a}$ & $452 \pm 27^{a}$ & $355 \pm 19^{b}$ & $334 \pm 24^{b}$ \\
\hline \multirow[t]{2}{*}{ Mucosal protein } & $\mathrm{mg} / \mathrm{g}$ mucosa & $167 \pm 3.9^{\mathrm{a}}$ & $165 \pm 5.8^{\mathrm{a}, \mathrm{b}}$ & $151 \pm 3.8^{b}$ & $153 \pm 5.5^{\mathrm{a}, \mathrm{b}}$ \\
\hline & $\mathrm{mg} /$ segment & $74.0 \pm 4.0^{\mathrm{a}}$ & $74.5 \pm 4.9^{\mathrm{a}}$ & $53.6 \pm 2.9^{b}$ & $51.1 \pm 4.1^{\mathrm{b}}$ \\
\hline \multicolumn{6}{|l|}{ Sucrase activity } \\
\hline & $\mathrm{U}^{4} / \mathrm{mg}$ protein & $5.74 \pm 0.36^{\mathrm{a}}$ & $5.89 \pm 0.27^{\mathrm{a}}$ & $6.11 \pm 0.19^{\mathrm{a}}$ & $6.50 \pm 0.69^{a}$ \\
\hline & $\mathrm{U} /$ segment & $408 \pm 28^{a}$ & $418 \pm 25^{a}$ & $328 \pm 19^{b}$ & $330 \pm 19^{b}$ \\
\hline \multicolumn{6}{|l|}{ LAPase activity } \\
\hline & $\mathrm{U} / \mathrm{mg}$ protein & $4.38 \pm 0.14^{\mathrm{a}}$ & $4.07 \pm 0.17^{\mathrm{a}}$ & $4.31 \pm 0.16^{\mathrm{a}}$ & $4.67 \pm 0.24^{\mathrm{a}}$ \\
\hline & $\mathrm{U} /$ segment & $311 \pm 14^{\mathrm{a}}$ & $302 \pm 18^{a}$ & $231 \pm 18^{b}$ & $231 \pm 15^{b}$ \\
\hline \multicolumn{6}{|c|}{${ }^{1}$ Insulin, $1.5 \mathrm{U} / \mathrm{rat} / \mathrm{day}$, was administered subcutaneously. } \\
\hline $\begin{array}{ll}{ }^{2} \text { Mean } \pm \text { SE }( \\
& (p<0.05) . \\
& \\
3 & \text { Second 15-cr } \\
4 & \text { Micromoles }\end{array}$ & $\begin{array}{l}\text {; means within } \\
\text { gment from the } \\
\text { ibstrate split per }\end{array}$ & $\begin{array}{l}\text { e not sharing } \\
\text { ylorus. } \\
\text { hour. }\end{array}$ & common sup & script letter diff & er significantly \\
\hline
\end{tabular}

in Table 4. Regardless of the administration of saline or insulin, differences between the basal group and the threonine-imbalance group in this experiment were similar to those between the respective groups in experiment 1 . Table 5 shows the results of experiment 4 . There were the same differences in food intake, gain in body weight, segmental weights of the small intestine and its mucosa, and intestinal enzyme activities of rats injected with saline between the groups as those in experiments 1 and 3. However, the administration of cortisol to rats fed the threonine-imbalanced diet increased the food intake, gain the body weight, liver weight and the segmental weights of the small intestine and its mucosa, although these increases were not statistically significant, except for the food intake and liver weight. Intestinal enzyme activities of rats fed the threonine-imbalanced diet were also increased by the administration of cortisol. The increase in segmental sucrase activity was statistically significant and this enzyme activity reached a level similar to that of the basal group. On the other hand, effects of the administration of cortisol on rats fed the basal diet were not notable as compared to those on rats fed the threonine-imbalanced diet, except that it reduced gain in body weight, and increased intestinal LAPase activities. The changes in body weight of rats fed ad libitum the basal diet or the threonine-imbalanced diet in experiment 5 are shown in Fig. 1, and there was the usual depression in food intake of rats fed the 
Table 5. Effect of cortisol on growth, food intake and intestinal sucrase and leucine aminopeptidase (LAPase) activities in rats fed a threonine-imbalanced diet (Experiment 4).

\begin{tabular}{|c|c|c|c|c|c|}
\hline Diet & & Basal & Basal & $\begin{array}{l}\text { Threonine- } \\
\text { imbalanced }\end{array}$ & $\begin{array}{l}\text { Threonine- } \\
\text { imbalanced }\end{array}$ \\
\hline Injection & & Saline & Cortisol $^{1}$ & Saline & Cortisol $^{1}$ \\
\hline Initial body wt. & g & $80.8 \pm 1.4^{2, \mathrm{a}}$ & $81.6 \pm 1.4^{\mathrm{a}}$ & $80.4 \pm 1.7^{\mathrm{a}}$ & $81.4 \pm 1.2^{\mathrm{a}}$ \\
\hline Body wt. gain & $\mathrm{g} / 3$ days & $3.3 \pm 0.7^{\mathrm{a}}$ & $1.2 \pm 0.4^{\mathrm{b}}$ & $-2.6 \pm 0.6^{c}$ & $-0.8 \pm 1.6^{\mathrm{b}}$ \\
\hline Food intake & g/day & $9.7 \pm 0.5^{\mathrm{a}}$ & $8.8 \pm 0.2^{\mathrm{a}}$ & $6.5 \pm 0.1^{\mathrm{b}}$ & $8.4 \pm 0.7^{\mathrm{a}}$ \\
\hline Liver wt. & $\mathrm{g}$ & $4.27 \pm 0.14^{\mathrm{a}}$ & $4.71 \pm 0.14^{\mathrm{a}}$ & $3.69 \pm 0.17^{b}$ & $4.51 \pm 0.28^{\mathrm{a}}$ \\
\hline Small intestine & $\mathrm{mg} /$ segment $^{3}$ & $667 \pm 20^{\mathrm{a}}$ & $671 \pm 9^{a}$ & $558 \pm 5^{\mathrm{b}}$ & $589 \pm 33^{\mathrm{a}, \mathrm{b}}$ \\
\hline Mucosa & $\mathrm{mg} /$ segment & $439 \pm 12^{\mathrm{a}}$ & $489 \pm 28^{a}$ & $362 \pm 12^{b}$ & $410 \pm 27^{\mathrm{a}, \mathrm{b}}$ \\
\hline \multirow[t]{2}{*}{ Mucosal protein } & $\mathrm{mg} / \mathrm{g}$ mucosa & $119 \pm 1^{\mathrm{a}}$ & $111 \pm 2^{b}$ & $105 \pm 5^{b}$ & $109 \pm 3^{b}$ \\
\hline & $\mathrm{mg} /$ segment & $51.7 \pm 1.0^{\mathrm{a}}$ & $54.3 \pm 4.0^{\mathrm{a}}$ & $37.9 \pm 1.1^{\mathrm{b}}$ & $44.7 \pm 3.6^{\mathrm{a}, \mathrm{b}}$ \\
\hline \multicolumn{6}{|l|}{ Sucrase activity } \\
\hline & $\mathrm{U}^{4} / \mathrm{mg}$ protein & $60.1 \pm 0.57^{\mathrm{a}}$ & $6.09 \pm 0.68^{\mathrm{a}}$ & $6.38 \pm 0.29^{\mathrm{a}}$ & $7.54 \pm 0.48^{\mathrm{a}}$ \\
\hline & U/segment & $311 \pm 26^{\mathrm{a}}$ & $331 \pm 25^{\mathrm{a}}$ & $242 \pm 11^{\mathrm{b}}$ & $337 \pm 26^{a}$ \\
\hline \multicolumn{6}{|l|}{ LAPase activity } \\
\hline & $\mathrm{U} / \mathrm{mg}$ protein & $2.86 \pm 0.05^{\mathrm{a}}$ & $3.46 \pm 0.45^{\mathrm{a}, \mathrm{b}}$ & $4.48 \pm 0.22^{\mathrm{b}}$ & $5.03 \pm 0.04^{\mathrm{c}}$ \\
\hline & $\mathrm{U} /$ segment & $147 \pm 5^{\mathrm{a}}$ & $188 \pm 17^{b}$ & $170 \pm 10^{\mathrm{a}, \mathrm{b}}$ & $224 \pm 18^{b}$ \\
\hline
\end{tabular}

1 Cortisol (hydrocortisone acetate), $1 \mathrm{mg} / \mathrm{rat} /$ day, was administered intraperitoneally.

${ }^{2}$ Mean \pm SE $(n=5)$; means within line not sharing a common superscript letter differ significantly $(p<0.05)$.

3 Second 15-cm segment from the pylorus.

4 Micromoles of substrate split per hour.

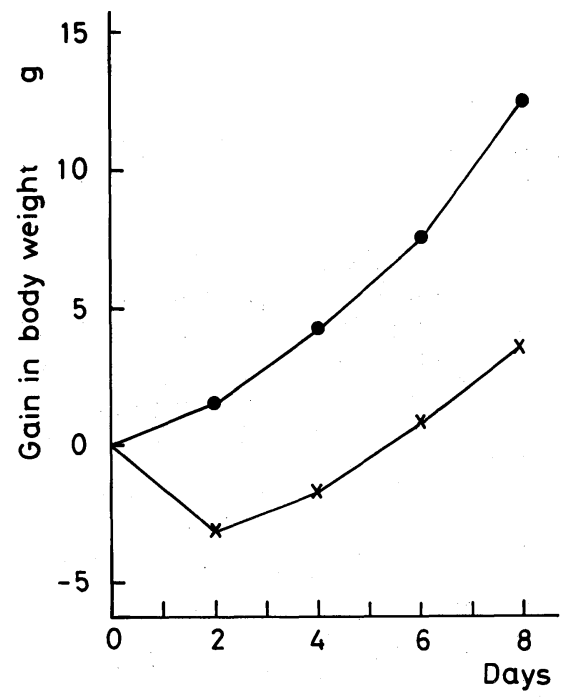

Fig. 1. Changes in body weight of rats fed ad libitum the basal diet and the threonine-imbalanced diet (Experiment 5). Basal diet, - - t threonine-imbalanced diet, $-\times-$. 
threonine-imbalanced diet as shown in Fig. 2. Rats in the threonine-imbalance group lost body weight for several days before they began to gain, whereas the basal group did not lose body weight. When rats were force-fed the threonineimbalanced diet in amounts approximately equal to those consumed by rats fed ad libitum the basal diet, their growth was stimulated and they gained as much as rats force-fed the same amount of the basal diet (Fig. 3). In this experiment differences

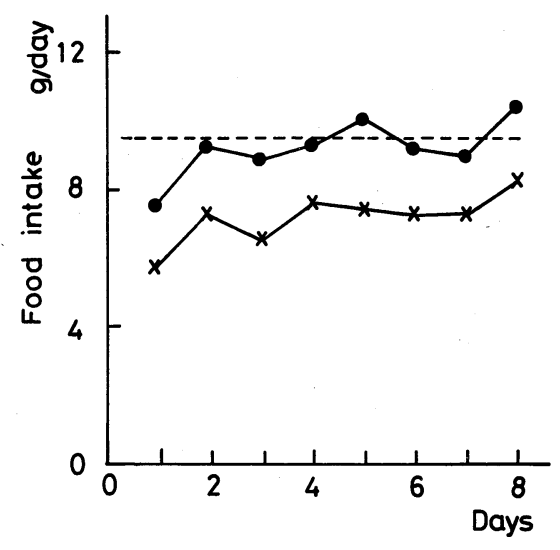

Fig. 2. Food intake of rats fed ad libitum the basal diet and the threonine-imbalanced diet, and that of rats force-fed (Experiment 5). Basal diet, - - - ; threonine-imbalanced diet, $-\times-$; forcefeeding,

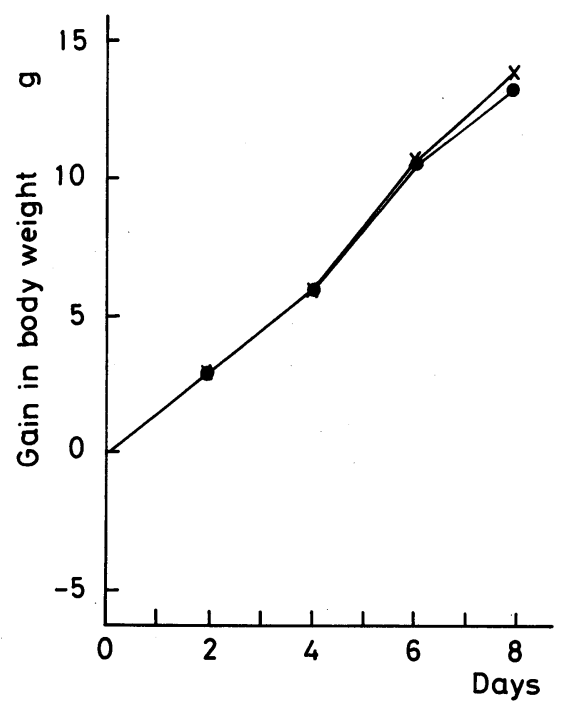

Fig. 3. Changes in body weight of rats force-fed the basal diet and the threonine-imbalanced diet (Experiment 5). Basal diet, - - - threonine-imbalanced diet, $-\times-$. 
Table 6. Effect of a threonine-imbalanced diet in rats fed ad libitum or force-fed on intestinal sucrase and leucine aminopeptidase

(LAPase) activities (Experiment 5).

\begin{tabular}{|c|c|c|c|c|c|}
\hline \multirow[b]{2}{*}{ Diet } & & \multicolumn{2}{|c|}{ Ad libitum feeding } & \multicolumn{2}{|c|}{ Force-feeding } \\
\hline & & Basal & $\begin{array}{l}\text { Threonine- } \\
\text { imbalanced }\end{array}$ & Basal & $\begin{array}{l}\text { Threonine- } \\
\text { imbalanced }\end{array}$ \\
\hline No. of rats & & 5 & 5 & 6 & 6 \\
\hline Initial body wt. & g & $77.4 \pm 2.6^{1, \mathrm{a}}$ & $80.2 \pm 1.7^{\mathrm{a}}$ & $83.0 \pm 2.0^{\mathrm{a}}$ & $82.8 \pm 2.1^{\mathrm{a}}$ \\
\hline Body wt. gain & $\mathrm{g} / 8$ days & $12.4 \pm 1.3^{\mathrm{a}}$ & $3.8 \pm 1.5^{\mathrm{b}}$ & $13.3 \pm 0.6^{\mathrm{a}}$ & $14.0 \pm 0.4^{\mathrm{a}}$ \\
\hline Food intake & g/day & $9.3 \pm 0.2^{\mathrm{a}}$ & $7.2 \pm 0.1^{\mathrm{b}}$ & 9.6 & 9.6 \\
\hline Liver wt. & $\mathrm{g}$ & $4.89 \pm 0.12^{\mathrm{a}}$ & $4.63 \pm 0.15^{\mathrm{a}}$ & $5.19 \pm 0.20^{\mathrm{a}}$ & $5.00 \pm 0.17^{a}$ \\
\hline Small intestine & $\mathrm{mg} /$ segment $^{2}$ & $752 \pm 35^{\mathrm{a}}$ & $670 \pm 27^{b}$ & $780 \pm 23^{a}$ & $773 \pm 17^{\mathrm{a}}$ \\
\hline Mucosa & $\mathrm{mg} /$ segment & $570 \pm 26^{a}$ & $482 \pm 27^{b}$ & $574 \pm 19^{a}$ & $575 \pm 17^{\mathrm{a}}$ \\
\hline \multirow{2}{*}{ Mucosal protein } & $\mathrm{mg} / \mathrm{g}$ mucosa & $132 \pm 3.3^{\mathrm{a}}$ & $123 \pm 1.3^{b}$ & $127 \pm 2.9^{\mathrm{a}, \mathrm{b}}$ & $124 \pm 3.6^{\mathrm{a}, \mathrm{b}}$ \\
\hline & $\mathrm{mg} /$ segment & $75.3 \pm 4.5^{\mathrm{a}}$ & $59.4 \pm 3.2^{\mathrm{b}}$ & $72.8 \pm 1.6^{\mathrm{a}}$ & $71.2 \pm 3.6^{\mathrm{a}}$ \\
\hline \multirow[t]{3}{*}{ Sucrase activity } & & & & & \\
\hline & $\mathrm{U}^{3} / \mathrm{mg}$ protein & $6.25 \pm 0.97^{\mathrm{a}}$ & $5.98 \pm 0.48^{\mathrm{a}}$ & $9.85 \pm 0.37^{b}$ & $11.10 \pm 0.88^{b}$ \\
\hline & U/segment & $494 \pm 47^{a}$ & $355 \pm 27^{\mathrm{b}}$ & $700 \pm 30^{c}$ & $790 \pm 73^{c}$ \\
\hline \multirow[t]{3}{*}{ LAPase activity } & & & & & \\
\hline & $\mathrm{U} / \mathrm{mg}$ protein & $3.54 \pm 0.25^{\mathrm{a}}$ & $3.54 \pm 0.22^{\mathrm{a}}$ & $3.27 \pm 0.14^{\mathrm{a}}$ & $3.86 \pm 0.34^{\mathrm{a}}$ \\
\hline & $\mathrm{U} /$ segment & $264 \pm 13^{a}$ & $213 \pm 25^{a}$ & $238 \pm 9^{a}$ & $275 \pm 28^{a}$ \\
\hline
\end{tabular}

1 Mean \pm SE; means within line not sharing a common superscript letter differ significantly $(p<0.05)$

2 Second $15-\mathrm{cm}$ segment from the pylorus.

4 Micromoles of substrate split per hour.

in the segmental weights of the small intestine and its mucosa and intestinal enzyme activities between both groups under an ad libitum feeding condition indicated a tendency similar to that in previous experiments (Table 6). On the other hand, under force-feeding conditions there were no differences in liver weight, segmental weights of the small intestine and its mucosa, and intestinal enzyme activities or in growth between the basal group and the threonine-imbalance group.

\section{DISCUSSION}

LEUNG et al. (7) reported that a threonine imbalance was created by adding 5.4 to $12.4 \%$ of an amino acid mixture lacking threonine to a low casein diet, and the severity of the adverse effect on food intake and growth increased with increasing concentration of the imbalancing amino acid mixture added to the diet. Prior to the present study, however, we observed the effects of adding $5.4 \%$ of an amino acid mixture devoid of threonine to a $6 \%$ casein diet on food intake and growth, but it did not always produce a depression in food intake and growth, although the composition of the amino acid mixture was similar to that used by LEUNG et al. (7), except that all amino acids in the mixture were $\mathrm{L}$-isomer, and carbohydrate in the 
diet was sucrose and starch. From these observations, the effect of the threonine imbalance was investigated with an addition of $8 \%$ of the amino acid mixture to a $6 \%$ casein diet supplemented with $0.3 \%$ L-methionine.

Throughout the results of the present study, it was demonstrated that the effects of the threonine imbalance on food intake and growth under different conditions, feeding ad libitum, cortisol administration and force-feeding, were generally in agreement with those reported by LEUNG et al. $(7,8)$ and IP and HARPER (9). With regard to the force-feeding experiment, however, LEUNG et al. (7) described how ninety $100-\mathrm{g}$ rats were trained to adapt to the force-feeding for 6 days and at the end of the adaptation period thirty-three rats were selected and used. The results obtained by such a selection procedure might be considered exceptional. The results of the force-feeding experiment in the present study, on the other hand, were obtained by using twelve rats adapted to the force-feeding among eighteen conventional rats. These findings indicated that force-feeding naturally stimulated the growth of rats receiving a threonine-imbalanced diet without causing obvious abnormalities.

In contrast to the result that the food intake of rats injected with cortisol and fed the threonine-imbalanced diet was not depressed, the administration of insulin affected neither food intake nor growth. Since there is no report on the stimulating effect of insulin administration in rats fed an amino acid-imbalanced diet on food intake and growth except for that reported by KUMTA and HARPER (10), in which rats were fed an amino acid-imbalanced diet containing fibrin, and HARPER (17) mentioned that insulin injection could not prevent the detrimental effects of an amino acid imbalance in rats fed severely imbalanced diets, and that the stimulating effect of insulin administration on food intake and growth might not be common in amino acid imbalances.

The length of the small intestine was altered little by different dietary conditions, whereas in several instances there was a substantial reduction in its weight, which was mainly due to reductions in mucosal weight $(3,18,19)$. The segmental weights of the small intestine and its mucosa were affected not only by the amount of food consumed but also by the quality and content of amino acids and protein in the diet (2-5). These findings were further confirmed by the results of experiment 2, which was conducted with rats pair-fed the basal diet against rats fed ad libitum the threonine-imbalanced diet. As shown in the results of experiment 5 (Table 6), however, there were no differences in the segmental weights of the small intestine and its mucosa between the basal group and the threonineimbalance group under force-feeding conditions. The discrepancy in the effects of the threonine-imbalanced diet on these weights between pair-feeding and forcefeeding might suggest that force-feeding per se had an increasing effect on these weights, regardless of dietary composition. This possibility is strongly denied by the findings that the weights of rats force-fed diets devoid of one indispensable amino acid or a protein-free diet were significantly lower than those of rats forcefed a complete amino acid diet (2). However, some investigators (20-23) have used 
rats on total parenteral nutrition to examine the effect of an absence of food from the gut on functional and structural parameters of the gastrointestinal tract, and demonstrated that the physiological response related to food ingestion, the tropic action of gastrin, was necessary for maintenance of the structural integrity of the gastrointestinal tract. Therefore, increases in the segmental weights of the small intestine and its mucosa due to force-feeding of the threonine-imbalanced diet might be mediated by increased unknown tropic factors, such as gastrin, affected by the increased threonine supply as a result of force-feeding of the threonineimbalanced diet.

LEUNG et al. (8) suggested that an increase in the concentration of amino acids in the plasma of cortisol-injected rats, possibly through some redistribution of amino acids in the body, might account for the prevention of food intake depression and the change in food preference of rats ingesting the imbalanced diet. On the other hand, WATSON et al. (24) found that in the intact dog chronic cortisol treatment increased both basal and meal-stimulated gastrin releases, although the acute administration of cortisol to fasted dogs did not alter the serum gastrin level. These findings suggested that the increased release of tropic factors, such as gastrin, of the gastrointestinal tract due to cortisol injection in rats fed ad libitum the threonine-imbalanced diet as well as due to force-feeding of this diet induced increases in the segmental weights of the small intestine and its mucosa, which was followed by the prevention of a depression in food intake and as a result the return to normal of the free amino acid pattern in the tissues.

It has been reported that segmental sucrase activities were affected not only by dietary sugar $(25,26)$ but also by the composition and content of amino acids and protein in a diet(1-5). These findings also were observed in the present study; segmental sucrase activities of rats fed ad libitum or pair-fed the basal diet were significantly different from those of rats fed ad libitum the threonine-imbalanced diet (Tables 2 to 5). However, differences in segmental sucrase activities between the basal group and the threonine-imbalance group were eliminated by the administration of cortisol and by force-feeding conditions, which were accompanied by increased amounts of food consumed. Force-feeding per se might be unable to increase segmental sucrase activities of rats fed the threonine-imbalanced diet to those of rats fed the basal diet, because segmental sucrase activities of rats force-fed diets devoid of one indispensable amino acid or a protein-free diet were significantly lower than those of rats force-fed a complete amino acid diet (2). These findings might explain the cases of the effects of cortisol injection and forcefeeding on the segmental weights of the small intestine and its mucosa of rats fed the threonine-imbalanced diet; the segmental sucrase activities were heightened by the increased release of tropic factors from the gastrointestinal tract either due to cortisol injection or due to force-feeding, and the increased supply of threonine due to the increased amount of food consumed. In the previous study (5), however, it was suggested that segmental sucrase activities were affected by the composition and the content of ingested amino acids and protein together with sucrose in the 
gastrointestinal lumen, but not by those in the tissues. This suggestion might be supported by the findings that the effects of a high sucrose diet under different feeding conditions on the segmental weights of the small intestine and segmental sucrase activities were not in parallel (2-6), and there were definite differences in segmental sucrase activities between rats fed ad libitum the basal diet and rats force-fed the basal or the threonine-imbalanced diet (Table 6). We supposed that the stimulating effect was induced by unknown factors, different from tropic factors such as gastrin, involved in the gastrointestinal tract, and produced at an initial stage in the daily regimen $(5,6)$. Significant increases in segmental sucrase activities of rats force-fed the diets might be produced by increased releases of these factors due to force-feeding as one of the adaptive responses to feeding pattern proposed by FÁBRY (27).

No definite differences in intestinal LAPase activities between the basal group and the threonine-imbalance group were observed throughout the present study. Although intestinal LAPase activities as well as intestinal sucrase activities, which were localized in the brush border membrane (28) were affected by the composition and content of dietary amino acids and protein $(3,29,30)$, the former was more affected by the contents of amino acids and protein in a diet than by the composition of them(3). The obscure differences in LAPase activity between the basal group and the threonine-imbalance group in the present study might be able to be explained by the relationship between this enzyme activity and the contents of amino acids and protein in each diet.

This study was supported in part by grant 356057 from the Ministry of Education, Science and Culture of Japan.

\section{REFERENCES}

1) Kimura, T., Suzuki, S., and Yoshida, A. (1975): Effect of force-feeding a valine-free diet on gastrointestinal function of rats. J. Nutr., 105, 257-265.

2) Kimura, T., Shiosaka, S., Sakakibara, A., Matsuoka, A., and Yoshida, A. (1976): Effect of dietary amino acids and food intake on intestinal sucrase and leucine aminopeptidase activities in rats. Nutr. Rep. Int., 14, 657-670.

3) Kimura, T., Seto, A., Kato, T., and Yoshida, A. (1977): Effect of dietary amino acids and protein on jejunal disaccharidase and leucine aminopeptidase activities of rats. Nutr. Rep. Int., 16, 621-630.

4) Kimura, T., Shiosaka, S., and Yoshida, A. (1978): Effect of dietary amino acids on jejunal sucrase and leucine aminopeptidase activities in rats. J. Nutr., 108, 1098-1103.

5) Kimura, T., Kato, T., Tsukazaki, K., and Yoshida, A. (1979): Effect of diets supplemented with amino acids on intestinal sucrase and leucine aminopeptidase activities in rats. J. Nutr. Sci. Vitaminol., 25, 195-204.

6) Kimura, T., Seto, A., and Yoshida, A.(1978): Effect of diets on intestinal disaccharidase and leucine aminopeptidase activities in refed rats. J. Nutr., 108, 1087-1097.

7) Leung, P. M-B., Roger, Q. R., and HARPer, A. E. (1968): Effect of amino acid imbalance in rats fed ad libitum, interval-fed, or force-fed. J. Nutr., 95, 474-482.

8) Leung, P. M-B., Roger, Q. R., and HARPER, A. E. (1968): Effect of cortisol on growth, food 
intake, dietary reference and plasma amino acid pattern of rats fed amino acid-imbalanced diets. J. Nutr., 96, 139-151.

9) IP, C. C., and HARPER, A. E. (1974): Liver polysome profiles and protein synthesis in rats fed a threonine-imbalanced diet. J. Nutr., 104, 252-263.

10) Kumta, U. S., and Harper, A. E. (1961): Amino acid balance and imbalance. VII. Effects of dietary additions of amino acids on food intake and blood urea concentration of rats fed lowprotein diets containing fibrin. J. Nutr., 74, 139-147.

11) HaRPER, A. E. (1959): Amino acid balance and imbalance. J. Nutr., 68, 405-418.

12) Kimura, T., and TaharA, M. (1971): Effect of force-feeding diets lacking leucine, valine, isoleucine, threonine, or methionine on amino acid catabolism in rats. J. Nutr., 101, 1646-1656.

13) Dahlqvist, A. (1964): Method for assay of intestinal disaccharidase. Anal. Biochem., 7, 18-25.

14) Goldberg, J. A., and Rutenburg, A. M. (1958): The colorimetric determination of leucine aminopeptidase in urine and serum of normal subjects and patients with cancer and other diseases. Cancer, 11, 283-291.

15) Lowry, O. H., Rosebrough, N. J., FarR, A. L., and Randall, R. J. (1951): Protein measurement with the Folin phenol reagent. J. Biol. Chem., 193, 265-275.

16) Snedecor, G. W. (1956): in Statistical Methods, Iowa State University Press, Ames, Iowa, pp. 75-88.

17) HARPER, A. E. (1964): Amino acid toxicities and imbalances, in Mammalian Protein Metabolism, Vol. 2., ed. by Munro, H. N., and Allison, J. B., Academic Press, New York, Chap. 13.

18) Newey, H., SANFord, P. A., and SMYTH, D. H. (1970): Effect of fasting on intestinal transfer of sugar and amino acids in vitro. J. Physiol. (London), 208, 705-724.

19) Lis, T. M., Crampton, R. E., and Matthews, D. M. (1972): Effect of dietary changes on intestinal absorption of L-methionine and L-methionylmethionine in the rats. Br. J. Nutr., 27, 159-167.

20) Levine, G. M., Deren, J. J., Steiger, E., and Zinno, R. (1974): Role of oral intake in maintenance of gut mass and disaccharide activity. Gastroenterology, 67, 975-982.

21) Castro, G. A., Copeland, E. M., Dudrick, S. J., and Johnson, L. R. (1975): Intestinal disaccharidase and peroxidase activities in parenterally nourished rats. J. Nutr., 105, 776-785.

22) Johnson, L. R., Copeland, E. M., Dudrick, S. S., Lichtenberger, L. M., and Castro, G. A. (1975): Structural and hormonal alterations in the gastrointestinal tract of parenterally fed rats. Gastroenterology, 68, 1177-1183.

23) Johnson, L. R., Lichtenberger, L. M., Copeland; E. M., Dudrick, S. J., and Castro, G. A. (1975): Action of gastrin on gastrointestinal structure and function. Gastroenterology, 68 , 1184-1192.

24) Watson, L. C., Reeder, D. R., and Thompson, J. C. (1974): Hydrocortisone administration and gastrin and gastric secretion in dogs. Arch. Surg., 109, 547-549.

25) Blair, D. G. R., Yakimets, W., and Tuba, J. (1963): Rat intestinal sucrase. II. The effects of rats' age and sex and of diet on sucrase activity. Can. J. Biochem. Physiol., 41, 917-929.

26) Deren, J. J., Broitman, S. A., and ZAMCHECK, N. (1967): Effect of diet upon intestinal disaccharidase and dissacharide absorption. J. Clin. Invest., 46, 186-195.

27) FABRy, P. (1969): in Feeding Pattern and Nutritional Adaptation, Butterworths, London, pp. 46-50.

28) EichHolz, A. (1969): Fractions of the brush border. Fed. Proc., 28, 30-34.

29) Nicholson, J. A., McCarthy, D. M., and KIM, Y. S. (1974): The responses of rat intestinal brush border and cytosol peptide hydrolase activities to variation in dietary protein content: Dietary regulation of intestinal peptide hydrolases. J. Clin. Invest., 54, 890-898.

30) SAito, M., and Suda, M. (1975): Effect of diet on enzymes of the brush border of the small intestine and kidney of rats. J. Nutr. Sci. Vitaminol., 21, 207-215. 